Esta publicación cientifica en formato digital es continuidad de la revista impresa ISSN-Versión Impresa 0798-1406 / ISSN-Versión on line 2542-3185Depósito legal pp
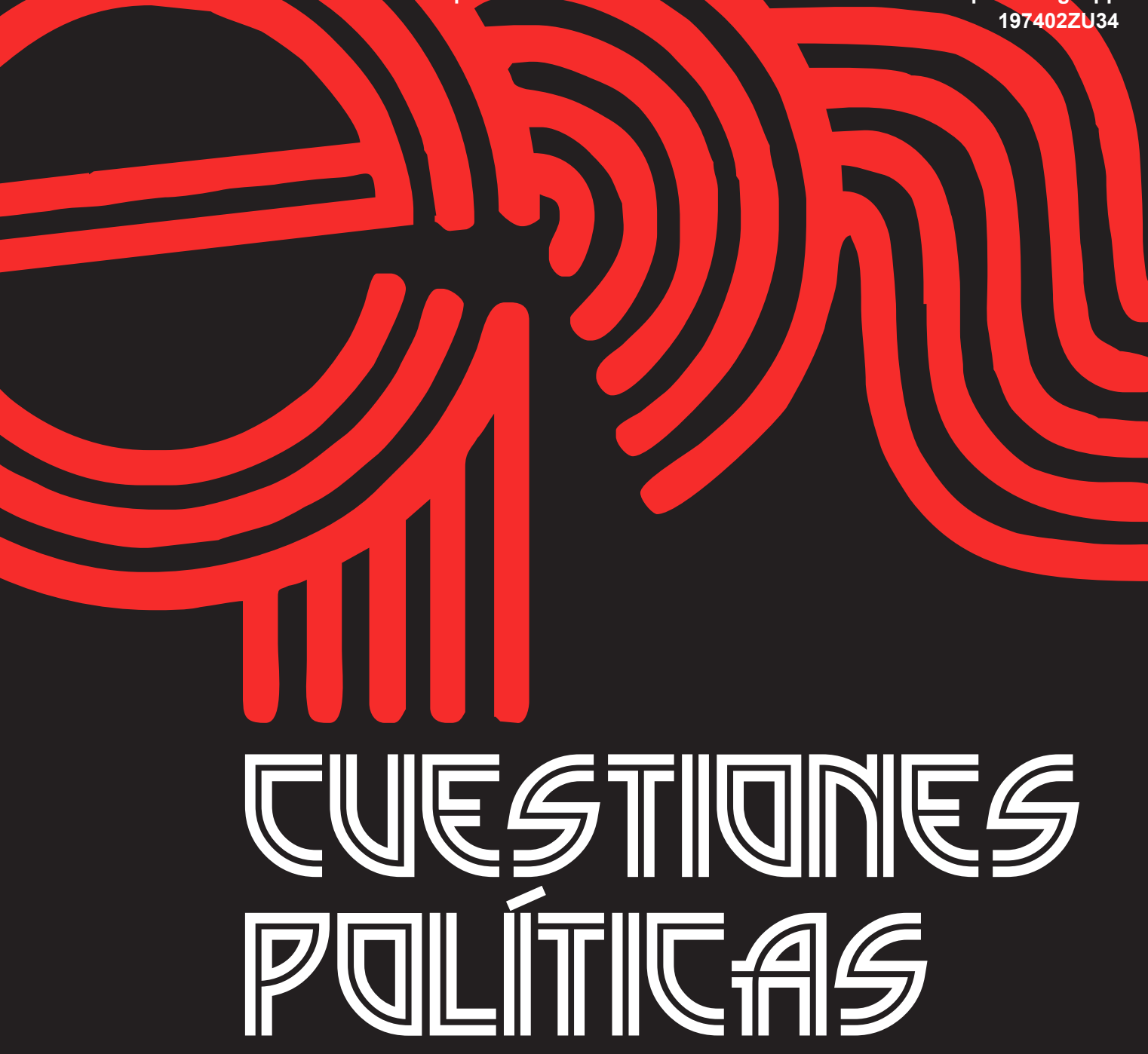

Instituto de Estudios Políticos y Derecho Público "Dr. Humberto J. La Roche" de la Facultad de Ciencias Jurídicas y Políticas de la Universidad del Zulia Maracaibo, Venezuela
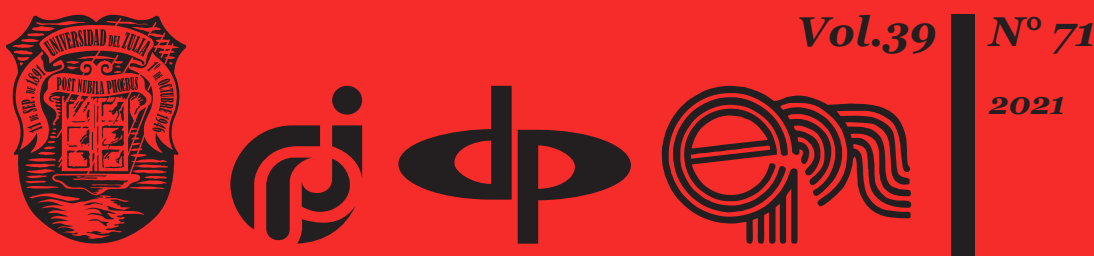


\title{
Standards of fair justice and their relationship to standards of proof in criminal proceedings
}

DOI: https://doi.org/10.46398/cuestpol.3971.58

\author{
Serhii Kovalchuk * \\ Liliia Korytko ** \\ Galyna Kret *** \\ Serhii Fomin **** \\ Volodymyr Hryniuk *****
}

\begin{abstract}
The purpose of the article is to define the concept, system and content of fair justice standards and outline their relationship to standards of evidence in criminal proceedings. The purpose of the study is to reveal the content of the right to a fair trial, distinguish fair justice standards and establish its relationship with standards of evidence in criminal proceedings. The research methodology consists of comparative law, structural system methods and formal legal methods. The study found that testing standards are covered by justice standards, expanding, specifying, and clarifying their content. The content of the fair justice standards "examination of the case by an independent and impartial tribunal established by law", "adversarial procedure", "equality of the parties", "frankness of the examination of evidence", "presumption of innocence" and reveals the "motivation of judicial decisions". It is concluded that each of these concepts is a heuristic contribution to test standards. As a result of the study, the author's definition of the concept of "fair justice standards" is formulated and the concept is based on its relationship with the standards of evidence in criminal proceedings.
\end{abstract}

\footnotetext{
* Doctor of Legal Science, Professor, Head of the Department of Criminal Procedure and Criminalistics of Ivano-Frankivsk Law Institute, National University «Odessa Law Academy», 76000, 13 Maximovycha str., Ivano-Frankivsk, Ukraine. ORCID ID: https://orcid.org/oooo-0001-6285-099X

** Doctor of Legal Science, Associate Professor, Head of the Department of General Legal and Human Sciences of Ivano-Frankivsk Law Institute, National University «Odessa Law Academy», 76000, 13 Maximovycha str., Ivano-Frankivsk, Ukraine. ORCID ID: https://orcid.org/oooo-0002-3812-205X

*** Doctor of Legal Science, Associate Professor, Judge of Grand Chamber, Supreme Court, 01043, 4 Pylypa Orlyka str., Kyiv, Ukraine. ORCID ID: https://orcid.org/oooo-0oo2-4906-4799

**** Candidate of Legal Science, Associate Professor, Judge of Criminal Cassation Court, Supreme Court, 01043, 4 Pylypa Orlyka str., Kyiv, Ukraine. ORCID ID: https://orcid.org/oooo-0oo3-1203-5633

***** Doctor of Legal Science, Associate Professor, Associate Professor of the Department of Criminal Procedure and Criminalistics, Taras Shevchenko Kyiv National University, 01033, 6o Volodymyrska str., Kyiv, Ukraine. ORCID ID: https://orcid.org/oooo-0002-6340-0584
} 
Serhï Kovalchuk, Liliia Korytko, Galyna Kret, Serhii Fomin y Volodymyr Hryniuk
958 Standards of fair justice and their relationship to standards of proof in criminal proceedings

Keywords: right to a fair trial; standards of impartial justice; test standards; criminal proceedings; European Court of Human Rights.

\section{Estándares de justicia justa y su relación con los estándares de prueba en procesos penales}

\section{Resumen}

El propósito del artículo es definir el concepto, sistema y contenido de los estándares de justicia justa y esbozar su relación con los estándares de prueba en los procesos penales. El objeto del estudio es revelar el contenido del derecho a un juicio justo, distinguir los estándares de justicia justa y establecer su relación con los estándares de prueba en los procesos penales. La metodología de investigación consiste en el derecho comparado, los métodos estructurales de sistema y los métodos legales formales. El estudio encontró que los estándares de prueba están cubiertos por los estándares de justicia, ampliando, especificando y aclarando su contenido. El contenido de las normas de justicia justa "examen del caso por un tribunal independiente e imparcial establecido por la ley", "procedimiento contradictorio", "igualdad de las partes", "franqueza del examen de las pruebas", "presunción de inocencia" y se revela la "motivación de las decisiones judiciales". Se concluye que cada uno de estos conceptos es un aporte heurístico para con estándares de prueba. Como resultado del estudio, se formula la definición del autor del concepto de "estándares de justicia justa" y se fundamenta el concepto en su relación con los estándares de prueba en los procesos penales.

Palabras clave: derecho a un juicio justo; estándares de justicia imparcial; estándares de prueba; procesos penales; Tribunal Europeo de Derechos Humanos.

\section{Introduction}

In the practice of international judicial institutions, the formation of standards of proof is largely the result of interpretation in specific cases of the provisions of international legal acts enshrining human rights and fundamental freedoms, which must be strictly observed by national authorities, including in criminal proceedings: the right to a fair trial. consideration, the right to liberty and security of person, the prohibition of torture, the right to respect for private and family life, housing and 
the secrecy of correspondence, etc. At the same time, the vast majority of standards of proof are formed by international judicial institutions, in particular, the European Court of Human Rights (hereinafter - the ECHR), as a result of the interpretation of regulations that enshrine the content of the right to a fair trial.

The multifaceted nature of this right has led to the development by international judicial institutions of a wide range of rules related to its implementation and enforcement, which in the doctrine of criminal procedure are defined as standards of fair justice. Drawing attention to their important role in ensuring the proper and effective administration of justice, scholars note that fair justice standards are a necessary part of human rights ideology, which, in modern democratic society, cannot but define its basic moral, philosophical, social, political and legal values (Morshchakova, 2012). The vast majority of standards of evidence are based on standards of fair justice, which necessitates the study of their concept and system, as well as the disclosure of the content of standards of fair justice in their relationship with the standards of evidence.

\section{Theoretical Framework or Literature Review}

In the doctrine of the criminal process, the study of both standards of fair justice and standards of proof is given considerable attention by scholars. In particular, to disclose the concept and content of the right to a fair trial as a basis for distinguishing the system of standards of fair justice turn Alekseevskaya (2016), Berezhansky (2017), Boggs (1998), Boryslavska (2021), Brich (2017), Harris (1967), Glovyuk (2011), Langford (2009), Mahoney (2004), Morshchakova (2012), Perezhniak, Balobanova, Timofieieva, Tavlui, and Poliuk (2021), Pogoretsky \& Hrytsenko (2012), Rabinovych \& Ratushna (2014), Sizam (2012), Tkachuk (2016), Trubnikova (2016), and Fulei (2015). The works of Basay, Hryniuk \& Kovalchuk (2019), Clermont and Sherwin (2002), Claude (2010), Kret (2020), Vapniarchuk, Trofymenko, Shylo, and Maryniv (2018), Tuzet (2021) are devoted to defining the concept, content, and system of standards of proof.

Despite the significant contribution of scholars to the development of fair justice and evidentiary standards, a significant number of its theoretical and practical aspects in the doctrine of criminal procedure have not been studied, disclosed insufficiently, or are characterized by debatable approaches to their disclosure. In particular, scholars ignore the relationship between fair justice standards and standards of proof as criminal procedural categories, the content of fair justice standards is not fully disclosed, and their system is ambiguously defined. 


\section{Methodology}

The methodological basis of the article was different methods of scientific knowledge: the comparative-legal method, stem-structural method, formal-legal method. Thus, the comparative-legal method made it possible to compare the standards of fair justice and the standards of proof. The application of the system-structural method ensured the disclosure of the content of the right to a fair trial and the separation of standards of fair justice.

Further, using the formal-legal method, the authors managed to formulate new definitions, used in this article.

\section{Results and Discussion}

\section{Standards of fair justice in relation to standards of proof in the context of ECHR practice}

In the doctrine of criminal procedure, the standards of fair justice are defined in close connection with the elements of the right to a fair trial. On the one hand, the combination of these elements, according to scientists, is the standard of a fair trial (Alekseevskaya, 2016). On the other hand, the right to a fair trial is the basis for distinguishing standards of fair justice: it is the elements of the content of this right that constitute the standards of fair justice.

An analysis of the provisions of Article 6 of the Convention and a study of the case-law of the ECHR, based on it, among the standards of fair justice, which are inextricably linked with the standards of evidence, allows us to include the following:

\section{Consideration of the case by an independent and impartial court established by law}

As the analysis of Article 6 of the Convention shows, this standard of fair justice includes three aspects: the independence of the judiciary; his impartiality; the creation of a court in the manner prescribed by law (United Nations, 1950). Along with these aspects, Article 14 of the International Covenant contains a direct reference to the fourth aspect - the jurisdiction of the court. At the same time, the requirements for the jurisdiction, independence, and impartiality of the court in paragraph 19 of General Comment № 32 to Article 14 of the International Covenant are recognized as absolute rights that are not subject to any exceptions (Human Rights Committee, 2007). 
Directly related to the standards of proof are two aspects of the fair justice standard under study: the impartiality of the court and its jurisdiction.

From the ECHR's point of view, impartiality means a lack of bias and commitment (paragraph 113 of the judgment of 11 July 2013 in Rudnichenko v. Ukraine) (ECHR, 2013). That is, in general, the impartiality of the court presupposes its lack of bias regarding the results of the criminal proceedings, which, in turn, leads to the formation of a corresponding belief in the minds of the participants in the criminal proceedings.

Characterizing the content of the impartiality of the court, the ECHR points to the existence of two approaches to its definition: subjective, which aims to establish the personal convictions of a particular judge in this case, and objective, which allows determining whether he has provided sufficient guarantees to rule out legitimate doubts in this regard (paragraph 41 of the judgment of 05.07.2007 in Sara Lind Eggertsdóttir v. Iceland) (ECHR, 2007). At the same time, the ECHR notes that there is no clear distinction between the two concepts, as the judge's conduct may not only raise objective doubts about the impartiality of the external observer (objective criterion) but also be related to his personal beliefs. (subjective criterion) (paragraph 119 of the judgment of 15 December 2005 in Kyprianou v. Cyprus) (ECHR, 2005).

The need to ensure the impartiality of the court has led to the development in the case-law of the ECHR of standards of evidence, taking into account the evidence to be formed by the court without a doubt in its impartiality concerning the results of criminal proceedings.

Disclosing the content of the right to a competent, independent, and impartial tribunal established by law, the Office for Democratic Institutions and Human Rights notes that "competence" usually presupposes compliance with the following three requirements: the competence of individual judges; jurisdiction of the court to make legally binding decisions and jurisdictional jurisdiction of the court. The last of these requirements are related to the standards of proof, according to which the evidence is to be formed by the court, taking into account the jurisdiction of the relevant criminal proceedings.

\section{Adversarial proceedings}

The provisions of Article 6 of the Convention do not specify the adversarial nature of the parties, although this standard of fair justice is widely used by the ECHR.

In the case-law of the ECHR, adversarial proceedings are defined as the principle of criminal proceedings, which means that in a criminal case, the prosecution and defense must be allowed to know the other party's 
position and evidence and express their views on them (paragraph 103 of the judgment in case of Mukhutdinov v. Russia) (ECHR, 2010). At the same time, national courts have a corresponding obligation to ensure these rights of the parties to criminal proceedings.

An integral prerequisite for the exercise of the rights that constitute the content of adversarial proceedings is the acquaintance of one party to the criminal proceedings with the evidence obtained by the other party. First of all, it concerns the protection of the rights of the defense, in connection with which the ECHR draws attention to the need to comply with two guarantees:

1) submission of evidence in the presence of the accused (paragraph 162 of the judgment of 11.12.2008 in Mirilashvili v. Russia) (ECHR, 2008), who as a general rule should have the right to be present and directly participate in the court hearing to establish the merits of the criminal charge against him, which presupposes the very concept of adversarial proceedings and may also derive from the guarantees established by Article $6 \S \S 3$ (c), (d) and (e) of the Convention (paragraph 81 of the judgment of 1 March 2006 in Sejdovic v. Italy) (ECHR, 2006).

2) the disclosure to the defense of the evidence obtained by the prosecution (paragraph 36 of the judgment of 16 December 1992 in Edwards v. The United Kingdom) (ECHR, 1992) and, in the event of nondisclosure, the provision by the trial court of its compliance with Article 6 of the Convention, the balance of interests: the public interest, on the one hand, and the interests of the defense, on the other, and its establishment of the urgency that led to the non-disclosure (paragraphs 62, 63 and Davis v. the United Kingdom) (ECHR, 2000).

The need to guarantee the adversarial nature of the trial has led to the development in the practice of the ECHR of certain standards of evidence, according to which: 1 ) the parties to the criminal proceedings are provided with equal opportunities to review the evidence submitted by another party; 2) the parties to the criminal proceedings shall be provided with equal opportunities to express their position on the evidence submitted by the other party, including the implementation of their assessment.

Examining the case-law of the ECHR on fair justice standards, scholars note the relationship between the two: adversarial proceedings as a standard developed by the ECHR and ensuring the rights of the accused, necessary and sufficient for protection, as a standard enshrined in Article 6 $\S 3$ of the Convention.

Thus, they point out that adversarial proceedings are seen by the ECHR as providing the party with a genuine opportunity to review the opposing party's arguments, challenge the evidence provided by it (including by personally questioning or participating in its interrogation), presenting its 
evidence, and proving its position in court. a case that the court would be entitled to and obliged to take into account when deciding the case, i.e. as ensuring the real possibility of a dispute between the parties (Trubnikova, 2016).

Directly related to the standards of proof is the right of the accused person to interrogate or demand the examination of prosecution witnesses, as well as to summon and examine defense witnesses on the same terms as prosecution witnesses (Article $6 \S 3$ (d) of the Convention). In particular, this right of the accused person corresponds to the standard of evidence formation.

\section{Equality of the parties}

Adversarial proceedings and equality of arms are quite rightly regarded as independent standards of fair justice, as they reflect different elements of the right to a fair trial. According to scholars, the difference between the requirement of procedural equality and adversarial proceedings requires that in the first case it is about the absolute rules of examination of evidence by the defense before the court, while in the second - the relative capabilities of the two parties in the process of submitting evidence to the court and their examination (Morshchakova, 2012).

\section{The immediacy of the evidence research}

Article 6 of the Convention does not contain a direct reference to this standard of fair justice, but in the case-law of the ECHR, it is based on the requirements of that article.

Based on the content of Article $6 \S 1$ and subparagraph (d) of the Convention, the ECHR states that an important element of a fair criminal proceeding is also the possibility for the accused to face a witness in the presence of a judge who finally decides the case. Such a principle of immediacy is an essential guarantee in criminal proceedings, as observations made by a court concerning the conduct of a witness and the veracity of his testimony may have significant consequences for the accused (ECHR, 2002, P.K v. Finland). Concerning Article $6 \S 3$ (d) of the ECHR Convention, it notes that it contains references to "witnesses" and, on strict interpretation, should not be applied to other evidence.

However, this term should be interpreted autonomously. It may also include victims, expert witnesses, and others who testify in court. In addition, there is clear evidence in the case law that this provision may apply not only to "witnesses" but also to other evidence (paragraphs 158 and 159 of the judgment of 11 December 2008 in Mirilashvili v. Russia) (ECHR, 2008), including material evidence (paragraphs 31, $37-40$ of the judgment of 09.05.2003 in the case of Georgios Papageorgiou v. Greece) (ECHR, 2003). 
Given the importance of the immediacy of the examination of the evidence for further judgment, the ECHR focuses on three aspects of its content:

1) as a duty of national courts to examine the evidence directly. In his view, judgments should be based on the evidence examined by national courts during a public hearing in the presence of the accused. At the same time, the ECHR does not exclude the possibility of using derivative evidence, although it pays attention to the peculiarities of their use. Initially, he repeatedly pointed out that the conviction should not be based solely or decisively on anonymous allegations (paragraph 76 of the judgment of 26 March 1996 in Doorson v. The Netherlands) (ECHR, 1996).

While acknowledging the flexibility of this approach, the ECHR eventually noted that accepting as evidence from a witness who did not appear in court, whose testimony obtained during the pre-trial investigation was the sole or decisive evidence of the defendant's guilt, did not automatically violate 1 of Article 6 of the Convention. The court based this finding on the fact that the inflexible application of the so-called "single or decisive rule" (according to which a trial is considered unfair if the conviction is based solely or decisively on evidence provided by a witness whom the accused was unable to question at any stage proceedings) would run counter to the Court's traditional approach to examining complaints of violations of the right to a fair trial guaranteed by Article $6 \S 1$ of the Convention, which is to determine whether the proceedings as a whole were fair. However, the adoption of such evidence, given the imminent risks to the fairness of the trial, is an important factor to be taken into account in balancing interests (paragraphs 146, 147 of the judgment of 15 December 2011 in Al-Khawaja and Tahery v. the United Kingdom») (ECHR, 2011).

To determine whether Article $6 \S 1$ (1) (d) of the Convention complied with a trial in which the testimony of witnesses who did not appear in court and were not questioned by the court was used as evidence, the ECHR carried out a three-stage test consistently providing them with answers to the following questions: i) whether there were good reasons for the witness not to appear in court and, accordingly, to accept as evidence the unverified testimony of the witness who did not appear; (ii) whether the testimony of a witness who did not appear was the sole or decisive basis for the conviction of the accused; (iii) whether there were sufficient balancing factors, including important procedural safeguards, to compensate for the difficulties encountered by the defense as a result of the admission of unverified evidence and to ensure the fairness of the trial as a whole (paragraph 107 of 15.12. 2015 in Case of Schatschaschwili v. Germany) (ECHR, 2015).

2) as requirements for the examination of evidence in this particular criminal proceeding. According to the ECHR, given the principle of the 
presumption of innocence and the right of the defendant to challenge any evidence against him, the criminal court must conduct a full, independent and comprehensive examination and assessment of the admissibility and reliability of evidence relating to the determination of the defendant's guilt, regardless of how the same evidence may be assessed in any other proceedings against other defendants (paragraph 212 of the judgment of 26 July 2011 in Huseyn and Others v. Azerbaijan) (ECHR, 2011).

3) as requirements for the invariability of the composition of the court. According to the ECHR, a change in the composition of the court of the first instance after hearing an important witness should normally lead to the reexamination of that witness (decision of 09.07.2002 in the case of P.K. v. Finland) (ECHR, 2002).

The need to guarantee the immediacy of the examination of evidence has led to the development in the practice of the ECHR of certain standards of proof, according to which:

1) evidence is subject to the formation by the court with the participation of the parties to the criminal proceedings, provided that the composition of the court remains unchanged.

2) data provided by absent witnesses will be carefully examined by national courts, taking into account all the circumstances of the case.

3) data provided by anonymous persons cannot be decisive for a court decision.

4) the evaluation of evidence is a function of national courts.

5) the appellate instance may not evaluate the evidence examined by the lower court if it does not carry out their direct examination.

\section{Presumption of innocence}

This standard of fair justice is enshrined in Article $6 \S 2$ of the Convention (United Nations, 1950).

The ECHR draws attention to the important role of the presumption of innocence in criminal proceedings, in the practice of which it is considered as an independent element of the right to a fair trial, which must be taken into account in any assessment of the fairness of the trial as a whole (paragraph 35 of 10.02. 1995 in the case of Allenet de Ribemont v. France) (ECHR, 1995).

These provisions are based on a wide range of elements of the studied standard of fair justice, which include:

1) imposing on the prosecution the burden of proving the guilt of a person in committing a criminal offense. 
2) inadmissibility of imposing on the accused the obligation to prove his innocence in committing a criminal offense.

3) ensuring the proof of a person's guilt in committing a criminal offense beyond a reasonable doubt.

4) inadmissibility of substantiation of accusation based on inadmissible evidence.

5) interpretation of all doubts in favor of the accused.

6) treatment of a person accused of committing a criminal offense as innocent.

The need to ensure the presumption of innocence has led to the use in the practice of the ECHR of one of the standards of formation of the level of persuasion required for a procedural decision - the standard of proof "beyond reasonable doubt", as well as other standards of evidence.

\section{Motivation of court decisions}

This standard of fair justice is not provided for in the provisions of Article 6 of the Convention but has found its application in the practice of the ECHR.

Recalling the importance of ensuring that national courts give reasons for judgments, the ECHR emphasizes that judgments of courts and litigation bodies must properly set out the grounds on which they are based (paragraph 26 of the judgment of 21 January 1999 in García Ruiz v. Spain) (ECHR, 1999). Although Article $6 \S 1$ of the Convention obliges courts to state reasons for their decisions, this cannot be construed as requiring a detailed answer to every argument (paragraph 107 of the judgment of o8 April 2008 in Grădinar v. Moldova) (ECHR, 2008).

The extent to which the obligation to state reasons for a decision applies may vary depending on the nature of the decision itself and should be determined by the circumstances of the case (paragraph 272 of the judgment of 21 April 2011 in Nechiporuk and Yonkalo v. Ukraine) (ECHR, 2011). At the same time, from the ECHR's point of view, courts have to consider arguments that the parties can present in court, as well as the differences between the High Contracting Parties in their laws, customs, legal doctrines, content and drafting. court decisions (paragraph 34 of the judgment of 1 July 2003 in Suominen v. Finland) (ECHR, 2003).

According to the ECHR, as scholars point out, a court decision can be considered motivated, which not only provides proper and sufficient reasons and grounds for its adoption but also provides an answer to the significant arguments of the criminal proceedings. This answer should not be formal, superficial, and abstract, but specific and reasoned on issues of 
both fact and law, relating to criminal-legal qualification, application of measures of criminal-legal nature, and the field of proof (Brich, 2017).

In this regard, the motivation of court decisions provides for the reasons and grounds for their adoption, including the reasons on which the court took into account the evidence submitted by one party to the criminal proceedings and rejected the evidence submitted by the other.

\section{Conclusions}

The standards of fair justice are a system of rules enshrined in the provisions of international legal acts and established in the practice of international judicial institutions, ensuring the proper administration of justice based on the right to a fair trial with strict observance of universally recognized human rights. Among the standards of fair justice are: 1) the right of access to justice; 2) consideration of the case by an independent and impartial court established by law; 3) ensuring a reasonable time for consideration of the case; 4) the right to a public hearing (publicity of the trial); 5) adversarial proceedings; 6) equality of the parties; 7) the immediacy of the study of evidence; 8) presumption of innocence; 9) ensuring the rights of the accused, necessary and sufficient for the exercise of protection; 10) guarantees of the right to question witnesses set out in Article $6 \S 3$ (d) of the Convention; 11) motivation of court decisions; 12) legal certainty.

The interdependence of the right to a fair trial and the standard of fair justice is that the elements of this right are the standards of fair justice. An analysis of the provisions of the Convention and the case-law of the ECHR shows the close interrelationship and interdependence of several fair justice and evidentiary standards. On the other hand, standards of evidence are covered by the standards of fair justice, expanding, specifying and clarifying their content in terms of forming by the subject of evidence the appropriate amount of relevant evidence and achieving a sufficient level of conviction sufficient to make a procedural decision.

\section{Bibliographic References}

ALEKSEEVSKAYA, Ekateryna. 2016. "Establishing a single level of legal guaranteesforafairtrialinthelegalregulationoflegalproceedingsisameans of effectively ensuring human rights" In: Law: Journal of theHigher School ofEconomics,Vol.2,pp.100-110.Availableonline.In:https://law-journal. hse.ru/data/2016/o7/13/1116455761/\%Do\%Bo\%Do\%BB\%Do\% B5\%Do\%BA\%D1\% 81\% Do\%B5\%Do\%B5\%Do\%B2\%D1\% 81\% Do\%BA\%Do\%Bo\%D1\%8F.pdf. Date of consultation: 12/03/2020. 
Serhii Kovalchuk, Liliia Korytko, Galyna Kret, Serhii Fomin y Volodymyr Hryniuk
Standards of fair justice and their relationship to standards of proof in criminal proceedings

BASAY, Viktor; HRYNIUK, Volodymyr; KOVALCHUK, Serhii. 2019. "Standards of proof in the criminal procedure of the United States of America and Ukraine: A comparative research" In: Amazonia Investiga. Vol. 8, Issue 22, pp. 550-559. Available online. In: https://amazoniainvestiga. info/index.php/amazonia/article/view/801. Date of consultation: 12/03/2020.

BEREZHANSKY, Genadii. 2017. "Features of understanding the right to a fair trial" In: Bulletin of criminal proceedings, Vol. 3, pp. 191-196. Available online. In: http://nbuv.gov.ua/UJRN/vkc_2017_3_23. Date of consultation: 12/006/2020.

BOGGS, Danny. 1998. “The Right to a Fair Trial” In: University of Chicago Legal Forum. Vol. 1, No. 2, pp. 1-24.

BORYSLAVSKA, Olena. 2021. "Judicial Reforms in Eastern Europe: Ensuring the Right to a Fair Trial or an Attack on the Independence of the Judiciary?" In: Access to Justice in Eastern Europe. Vol. 1, No. 9, pp. 122142.

BRICH, Larysa. 2017. "The right to a reasoned court decision in criminal proceedings as a component of the right to a fair trial in the interpretation of the ECHR" In: University scientific notes. Vol. 63, pp. 268-281. Available online. In: http://nbuv.gov.ua/UJRN/Unzap_2017_3_26. Date of consultation: 12/06/2020.

CLAUDE, Ophelia. 2010. "A Comparative Approach to Enforced Disappearances in the Inter-American Court of Human Rights and the ECHR Jurisprudence” In: Intercultural Human Rights Law Review. Vol. 5, pp. 407-462. Available online. In: https://www.stu.edu/portals/law/ docs/human-rights/ihrlr/volumes/5/407-462-opheliaclaude-acompara tiveapproachtoenforceddisappearancesintheinter-americancourtofhum anrightsandtheeuropeancourtofhumanrightsjurisprudence.pdf. Date of consultation: 12/12/2020.

CLERMONT, Kevin; SHERWIN, Emily. 2002. "A Comparative View of Standards of Proof" In: American Journal of Comparative Law, 50, 243-275. Available online. In: https://scholarship.law.cornell.edu/ facpub/222. Date of consultation: 12/12/2020.

ECHR, 2008. Grădinar v. Moldova: Judgment. Strasburg, France.

ECHR. 1992. Edwards v. the United Kingdom: Judgment. Strasburg, France.

ECHR. 1995. Allenet de Ribemont v. France: Judgment. Strasburg, France.

ECHR. 1996. Doorson v. the Netherlands: Judgment. Strasburg, France. 
ECHR. 1999. García Ruiz v. Spain: Judgment.

ECHR. 2000. Rowe and Davis v. the United Kingdom: Judgment. Strasburg, France.

ECHR. 2002. P.K. v. Finland: Final Decision. Strasburg, France.

ECHR. 2003. Georgios Papageorgiou v. Greece: Judgment of the ECHR from 9 May 2003. Available online. In: http://hudoc.echr.coe.int/ eng?i=001-61091. Date of consultation: 12/12/2020.

ECHR. 2003. Suominen v. Finland: Judgment. Strasburg, France.

ECHR. 2005. Kyprianou v. Cyprus: Judgment. Strasburg, France.

ECHR. 2006. Sejdovic v. Italy: Judgment. Strasburg, France.

ECHR. 2007. Sara Lind Eggertsdóttir v. Iceland: Judgment of the ECHR from 5 July 2007. Available online. In: http://hudoc.echr.coe.int/ fre? $\mathrm{i}=001-81432$. Date of consultation: 16/08/2020.

ECHR. 2008. Mirilashvili v. Russia: Judgment. Strasburg, France.

ECHR. 2010. Mukhutdinov v. Russia: Judgment of the ECHR from 10 June 2010. Available online. In: http://hudoc.echr.coe.int/eng?i=001-99212. Date of consultation: 12/10/2020.

ECHR. 2011. Huseyn and Others v. Azerbaijan: Judgment of the ECHR from 26 July 2011. Available online. In: http://hudoc.echr.coe.int/ eng?i=001-105823. Date of consultation: 12/12/2020.

ECHR. 2011. Al-Khawaja and Tahery v. the United Kingdom: Judgment. Strasburg, France.

ECHR. 2011. Nechiporuk and Yonkalo v. Ukraine: Judgment. ECHR, 2011. Available online. In: http://hudoc.echr.coe.int/eng?i=001-104613. Date of consultation: 12/10/2020.

ECHR. 2013. Rudnichenko v. Ukraine: Judgment. Strasburg, France.

ECHR. 2015. Schatschaschwili v. Germany: Judgment. Strasburg, France.

GLOVYUK, Iryna. 2011. "Access to court in criminal proceedings: problems of theory" In: Journal of the Academy of Advocacy of Ukraine. Vol. 4, Issue 2, No. 11, pp. 1-7.

HARRIS, David. 1967. "The Right to a Fair Trial in Criminal Proceedings as a Human Right" In: The International and Comparative Law Quarterly, Vol. 16, Issue 2, pp. 352-378. 
Serhii Kovalchuk, Liliia Korytko, Galyna Kret, Serhii Fomin y Volodymyr Hryniuk

970

Standards of fair justice and their relationship to standards of proof in criminal proceedings

HUMAN RIGHTS COMMITTEE (HRC). 2007. General comment no. 32, Article 14, Right to equality before courts and tribunals and to fair trial, 23 August 2007, CCPR/C/GC/32. Available online. In: https://www. refworld.org/docid/478b2b2f2.html. Date of consultation: 12/12/2020.

KRET, Galyna. 2020. International standards of proof in the criminal process of Ukraine: theoretial, legal and practical foundations. (doctoral thesis). National University «Odesa Law Academy», Odesa. Available online. In: http://dspace.onua.edu.ua/bitstream/ handle/11300/13756/\%Do\%9A\%D1\%80\%Do\%B5\%D1\%82\%20 \%Do\%93.\%Do\%Ao.pdf?sequence=1\&isAllowed=y. Dateof consultation: $12 / 10 / 2020$.

LANGFORD, Ian. 2009. "Fair Trial: The History of an Idea" In: Journal of Human Rights. Vol. 8, No. 1, pp. 37-52.

MAHONEY, Paul. 2004. "Right to a Fair Trial in Criminal Matters under Article 6 E.C.H.R” In: Judicial Studies Institute Journal. Vol, 4, No. 2, pp. 107129.

MORSHCHAKOVA, Tamara. Ed. 2012. Fair justice standards (international and national practices). Available online. In: http://kalinovsky-k.narod. ru/b/Morshakova_min.pdf. Date of consultation: 12/10/2020.

PEREZHNIAK, Boris; BALOBANOVA, Dariia; TIMOFIEIEVA, Liliia; TAVLUI, Olena; POLIUK, Yuliia. 2021. "The right to a fair trial: conceptual rethinking in an era of quarantine restrictions" In: Amazonia Investiga, Vol.1,No.38,pp.168-177.Availableonline.In:https://doi.org/10.34069/ $\mathrm{AI} / 2021.38 .02 .16$. Date of consultation: 16/08/2020.

POGORETSKY, Mykola; HRYTSENKO, Ivan. 2012. "The right to a fair trial” In: Bulletin of Taras Shevchenko National University of Kyiv. Legal sciences. Vol. 91, pp. 4-8.

RABINOVYCH Patro; RATUSHNA Bogdana. 2014. "General theoretical problems of the right to proper proof in Ukrainian proceedings (in the light of the practice of the Strasbourg court)" In: Bulletin of the National Academy of Legal Sciences of Ukraine. Vol. 3, No. 78, pp. 7-19. Available online. In: http://visnyk.kh.ua/web/uploads/pdf/ilovepdf_com-7-19. pdf Date of consultation: 16/08/2020.

SIZAM, Natalia. 2012. "The system of elements of the right to a fair trial" In: Scientific Bulletin of Uzhhorod National University. Law Series. Vol. 4, pp. 194-199.

TKACHUK, Oleh. 2016. "Classification of elements of the right to a fair trial: national theory and practice of the ECHR" In: Prykarpattya Legal Bulletin. Vol. 1, pp. 71-77. 
TRUBNIKOVA, Tetiana. 2016. "Problems of proof in a fair trial and their reflection in the legal positions of the ECHR: challenges for the Russian science of criminal procedure and law enforcement practice" In: Criminal Justice, Vol. 1, pp. 135-147. Available online. In: https://cyberleninka. $\mathrm{ru} /$ article/n/problemy-dokazyvaniya-v-spravedlivom-sudebnomrazbiratelstve-i-ih-otrazhenie-v-pravovyh-pozitsiyah-espch-vyzovydlya-rossiyskoy-nauki. Date of consultation: 16/08/2020.

TUZET, Giovanni 2021. "Evidence Assessment and Standards of Proof: a Messy Issue. Quaestio facti” In: International Journal on Evidential Legal Reasoning. Seccion: Ensayos, Vol. 2, pp. 87-113. Available online. In: https://revistes.udg.edu/quaestio-facti/article/ download/22480/26276. Date of consultation: 16/08/2020.

UNITED NATIONS. 1950. Convention for the Protection of Human Rights and Fundamental Freedoms. Available online. In: https://www.echr.coe.int/ documents/convention_eng.pdf. Date of consultation: 16/06/2020.

VAPNIARCHUK, Viacheslav: TROFYMENKO, Volodymyr; SHYLO, Olha; MARYNIV, Volodymy. 2018. "Standards of Criminal Procedure Evidence" In: Journal of Advanced Research in Law and Economics. Vol. IX, No. 7, pp. 2472-2480. 

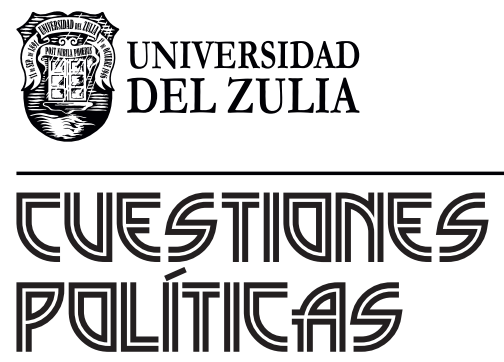

Vol. 39 N $^{\circ} 71$

Esta revista fue editada en formato digital y publicada en diciembre de 2021, por el Fondo Editorial Serbiluz, Universidad del Zulia. Maracaibo-Venezuela 